\title{
Concordance between otic cytology and culture in diagnosis of external otitis canine by Malassezia spp
}

\section{Concordancia entre citología ótica y cultivo en el diagnóstico de otitis externa canina por Malassezia spp}

\author{
Adriana Pulido-Villamarín, ${ }^{1 *}$ M.Sc, Rubiela Castañeda-Salazar, ${ }^{1}$ M.Sc, \\ Melva Linares-Linares, ${ }^{1}$ M.Sc, Marcela Mercado-Reyes, ${ }^{2}$ M.Sc.
}

\begin{abstract}
${ }^{1}$ Pontificia Universidad Javeriana, Facultad de Ciencias, Departamento de Microbiología, Unidad de Investigaciones Agropecuarias -UNIDIA-. Carrera 7 No. 43-82. Bogotá- Colombia. ${ }^{2}$ Instituto Nacional de Salud, Dirección de Vigilancia y Análisis de Riesgo en Salud Pública, Subdirección de Prevención y Análisis de Riesgo. Avenida Calle 26 \#51-20. Bogotá- Colombia. *Correspondence: adriana.pulido@ javeriana.edu.co
\end{abstract}

Received: March 2014; Accepted: December 2014.

\begin{abstract}
Objective. To determine the correlation between microbiological culture and otic cytology for diagnoses of external otitis by Malassezia in dogs. Materials and methods. 158 ear swabs of dogs with clinical diagnosis of external otitis were analyzed by cytology, mycological culture and metabolic tests. Results. Were obtained a positive results by cytology of $62 \%$ and $75.3 \%$ by culture. The $31.1 \%$ of isolates were identified as $M$. pachydermatis, $12.6 \%$ as $M$. furfur and $56.3 \%$ were classified as Malassezia spp., because was not possible to define the species. We found a positive concordance between cytology and culture for Malassezia spp., of 0.76 with a kappa index of 0.448 (95\% CI 0.30 to 0.60 ) which represents a moderate strength of concordance between the two techniques, without regard the identified species. Conclusions. The use of a diagnostic test is not enough to establish the participation of Malassezia spp., as a causal disease agent.
\end{abstract}

Key words: Canis familiaris, diagnostic techniques, Malassezia, otitis externa (Source: CAB).

\section{RESUMEN}

Objetivo. Determinar la concordancia entre el cultivo microbiológico y la citología ótica para el diagnóstico de otitis externa causada por Malassezia spp. en caninos. Materiales y métodos. Se analizaron 158 muestras de hisopados de caninos con diagnóstico clínico de otitis externa, todas las muestras fueron analizadas mediante citología, cultivo micológico y pruebas metabólicas. Resultados. Se obtuvo una positividad mediante citología del $62 \%$ y por cultivo del $75.3 \%$. El $31.1 \%$ de los aislamientos fueron identificados como M. pachydermatis, el $12.6 \%$ como $M$. furfur y un $56.3 \%$ se clasificó como Malassezia spp., dado que bioquímicamente no fue posible hallar su especie. Se determinó una concordancia observada entre técnicas positivas para Malassezia spp. de 0.76 con índice Kappa de 0.448 IC $95 \%$ (0.30 - 0.60) lo que representa una fuerza de concordancia moderada entre las dos técnicas, sin tener en cuenta la especie identificada. Conclusiones. El uso de una prueba diagnóstica no es suficiente para establecer la participación de Malassezia pachydermatis como agente causal de enfermedad.

Palabras clave: Canis familiaris, técnicas diagnósticas, Malassezia, otitis externa (Fuente: CAB). 


\section{INTRODUCTION}

One of the most common causes of veterinary consult in dogs are ear diseases which must be diagnosed and treated. One of these conditions is external otitis whose reported prevalence is $10-20 \%(1,2)$, with a wide variety of causative agents. Malassezia spp., is the predominant organism in $50-83 \%$ of cases $(3,4)$, presenting themselves alone or in association with other infectious agents $(5,6)$. Malassezia spp., has been recognized as commensal of the skin and mucous membranes on humans and animals (7), however it has been implicated in disease processes that go from either superficial infections to systemic processes, which are favored by exogenous host factors (environmental conditions) or endogenous (skin integrity, immunological conditions)(8-10).

Malassezia spp., are lipophilic yeasts; from which 14 species, have been recognized: Malassezia furfur, M. pachydermatis, M. globosa, M. restricta, M. obtusa, M. slooffiae, $M$. sympodialis, M. dermatis, M. yamatoensis, $M$. nana, $M$. caprae, $M$. cuniculi sp. nov, $M$. dermatis, $M$. japonica, M. equina (11-16) which have been identified by morphology, metabolic profile and molecular tests $(3,4)$.

The laboratory diagnosis of external otitis is made by Wright staining cytology, Giemsa and Gram, that look for the presence of yeast structures whose ratio $\geq 5$ cells per microscopic field (40X) is considered as indicator of pathology, while the presence of lesser amount of yeast indicates of commensal microorganism $(2-4,8,17,18)$, on the other hand, the Malassezia cultivation is hard to do due to its strict nutritional requirements and morphological variability making difficult its isolation and identification, therefore, microbiological characterization is done only for epidemiological purposes or in cases of chronic external otitis and media otitis (1), but it should be noted that the identification of the etiologic agent by culture confirms the clinical suspicion and achieves therapeutic success (5).

Given that laboratory diagnosis is done by cytology and/or culture, the objective of this study was to determine the correlation of these techniques for the analyzed cases.

\section{MATERIALS AND METHODS}

Study population. 158 ear swabs of dogs with clinical diagnosis of external otitis were submitted by four veterinary clinics in Bogotá. All samples were analyzed by cytology and culture.

\section{INTRODUCCIÓN}

Una de las causas más comunes en consulta veterinaria en caninos son las enfermedades óticas las cuales deben diagnosticarse y tratarse. Una de estas condiciones es la otitis externa cuya prevalencia reportada es de $10-20 \%(1,2)$, con una amplia variedad de agentes causales. Malassezia spp., es el organismo predominante en $50-83 \%$ de los casos $(3,4)$ presentándose sola o en asociación con otros agentes infecciosos $(5,6)$. Malassezia spp., ha sido reconocida como microbiota comensal de la piel y membranas mucosas en humanos y animales (7), sin embargo ha sido implicada en procesos de enfermedad que van desde infecciones superficiales a procesos sistémicos, que han sido favorecidos por factores exógenos (condiciones ambientales) o endógenos (integridad de la piel, condiciones inmunológicas) al hospedero (8-10).

Malassezia spp., son levaduras lipofílicas; de las cuales se han reconocido 14 especies: Malassezia furfur, M. pachydermatis, M. globosa, M. restricta, M. obtusa, M. slooffiae, M. sympodialis, M. dermatis, M. yamatoensis, M. nana, M. caprae, M. cuniculi sp. nov, M. dermatis, M. japonica, M. equina (11-16) que han sido identificadas por morfología, perfil metabólico y pruebas moleculares $(3,4)$.

El diagnóstico de laboratorio de otitis externa se realiza mediante citología con tinción de Wright, Giemsa y Gram, que buscan la presencia de estructuras levaduriformes cuya presencia $\geq 5$ células por campo microscópico $(40 x)$ es considerada un indicador de patología, mientras la presencia de una menor cantidad de levaduras indica microbiota comensal $(2-4,8,17,18)$, por otra parte, el cultivo de Malassezia es difícil de hacer debido a los requerimientos nutricionales estrictos y a la variabilidad morfológica que hace difícil su aislamiento e identificación, por ende, la caracterización microbiológica se lleva a cabo para efectos epidemiológicos o en casos de otitis crónica externa y otitis media (1), pero debe tenerse en cuenta que la identificación del agente etiológico por cultivo confirma la sospecha clínica y permite el éxito terapéutico (5).

Dado que el diagnóstico de laboratorio se da por citología y/o cultivo, el objetivo de este estudio fue determinar la correlación entre estas técnicas para los casos analizados.

\section{MATERIALES Y MÉTODOS}

Población de estudio. 158 hisopados óticos de caninos con diagnóstico clínico de otitis externa remitidos por cuatro clínicas veterinarias en 
Cytology. Wright staining was performed to determine the presence of yeast, by semiquantitative scale by crosses, thus: 1 to 5 cells/ field $(+), 6$ to 10 cells/field $(++), 10$ to 19 cells/field $(+++)$ and $>19$ cells/field $(++++)$ $(1,3,4,18,19)$.

Culture and identification. Samples were cultured in Sabouraud agar (Oxoid, Wade Road, Basingstoke, UK.) and Dixon's (Mycosell 36 $\mathrm{g} / \mathrm{L}$ Malt extract $36 \mathrm{~g} / \mathrm{L}$, OxBil $20 \mathrm{~g} / \mathrm{L}$, Ac Oleic $2 \mathrm{ml} / \mathrm{L}$, glycerol $2 \mathrm{ml} / \mathrm{L}$, Tween $4010 \mathrm{ml} / \mathrm{L}$, Chloramphenicol $0.5 \mathrm{~g} / \mathrm{L}$ ) and incubated at $32^{\circ} \mathrm{C}$ for one week. Positive cultures were evaluated microscopically by Gram stain and identified by biochemical tests (urease activity, bile esculin hydrolysis, growth on agar Sabouraud assimilation of Tween 20, 40, 60, 80 (Merck KGaA, Darmstadt, Germany) and cremophor (Sigma-Aldrich, St Louis, MO, USA) $(11,12)$, using reference strains: $M$. furfur CBS 7019, $M$. pachydermatis CBS $1879, M$. symphodialis CBS 7222, M. restricta CBS 7877, M. slooffiae CBS 7956 and M. globosa CBS 7966.

Statistical Analysis. A prospective study was performed to determine the diagnostic value of cytology and culture for diagnosis of external otitis caused by Malassezia spp. Data were analyzed in SPSS 1.9; for quantitative variables descriptive statistics were done and for the ratio of diagnostic tests were analyzed for consistency of agreement by Kappa index.

\section{RESULTS}

Of the 158 samples analyzed by cytology, $62 \%$ (98/158) had the presence of yeast in different degrees as shown in table 1 .

Table 1. Semi-quantitative cytology in otic samples.

\begin{tabular}{cccc}
\hline & Semicuantitative scale & $\mathbf{n}$ & \% \\
\hline & Negative & 60 & 38 \\
Presence of yeast & + & 37 & 23.4 \\
& ++ & 23 & 14.6 \\
& +++ & 27 & 17 \\
& ++++ & 11 & 7 \\
\hline
\end{tabular}

The microbiological culture for Malassezia was positive in $75.3 \%(119 / 158)$, of which by biochemical characterization, $31.1 \%(37 / 119)$ were classified as $M$. pachydermatis, $12.6 \%$ $(15 / 119)$ as $M$. furfur and $56.3 \%$ (67/119) corresponded to Malassezia spp. In the corresponding smears were observed different cytological findings (Table 2 ).
Bogotá. Todas las muestras fueron analizadas por citología y cultivo.

Citología. Se llevó a cabo tinción de Wright para determinar la presencia de levaduras, mediante escala semicuantitativa por cruces, así: 1 a 5 células/campo $(+), 6$ a 10 células/campo $(++), 10$ a 19 células/campo $(+++)$ y $>19$ células/campo $(++++)(1,3,4,18,19)$.

Cultivo e identificación. Las muestras fueron cultivadas en Agar Sabouraud (Oxoid, Wade Road, Basingstoke, UK.) y Dixon's (Mycosell 36 $\mathrm{g} / \mathrm{L}$ Extracto de Malta $36 \mathrm{~g} / \mathrm{L}$, OxBil $20 \mathrm{~g} / \mathrm{L}$, Ac Oleic $2 \mathrm{ml} / \mathrm{L}$, glicerol $2 \mathrm{ml} / \mathrm{L}$, Tween $4010 \mathrm{ml} / \mathrm{L}$, Cloramfenicol $0.5 \mathrm{~g} / \mathrm{L}$ ) e incubadas a $32^{\circ} \mathrm{C}$ por una semana. Los cultivos positivos fueron evaluados microscópicamente por tinción de Gram e identificados por pruebas bioquímicas (actividad ureasa, hidrólisis de bilis esculina, crecimiento en Agar Sabouraud, asimilación de Tween 20, 40, 60, 80 (Merck KGaA, Darmstadt, Alemania) y cremofor (Sigma-Aldrich, St Louis, MO, USA) $(11,12)$, utilizando las cepas de referencia: $M$. furfur CBS 7019, M. pachydermatis CBS 1879, M. symphodialis CBS 7222, M. restricta CBS 7877, M. slooffiae CBS 7956 y M. globosa CBS 7966.

Análisis Estadístico. Se realizó un estudio prospectivo para determinar el valor diagnóstico de la citología y cultivo para el diagnóstico de la otitis externa causada por Malassezia spp. Los datos fueron analizados en SPSS 1.9; para las variables cuantitativas y para la relación de las pruebas diagnósticas se realizó un análisis de concordancia por consistencia mediante el índice Kappa.

\section{RESULTADOS}

De las 158 muestras analizadas por citología, en el $62 \%(98 / 158)$ se evidenció la presencia de levaduras en diferentes grados como se observa en la tabla 1.

El cultivo microbiológico de Malassezia fue positivo en el $75.3 \%(119 / 158)$, de los cuales mediante caracterización bioquímica el $31.1 \%$

Table 2. Cytological findings according to Malassezia species isolated.

\begin{tabular}{cccc}
\hline \multirow{2}{*}{$\begin{array}{c}\text { Semicuantitative } \\
\text { scale }\end{array}$} & \multicolumn{3}{c}{ Malassezia species } \\
\cline { 2 - 4 } & $\begin{array}{c}\text { M. pachydermatis } \\
\mathbf{n}\end{array}$ & $\begin{array}{c}\text { M. furfur } \\
\mathbf{n}\end{array}$ & $\begin{array}{c}\text { Malassezia spp. } \\
\mathbf{n}\end{array}$ \\
\hline Negative & 10 & 4 & 16 \\
+ & 11 & 2 & 16 \\
++ & 4 & 5 & 13 \\
+++ & 11 & 2 & 13 \\
++++ & 1 & 2 & 9 \\
\hline
\end{tabular}


The observed concordance between positive otic cytology for Malassezia Vs positive culture was 0.76 and the Kappa index was 0.448 (95\% CI 0.30 to 0.60 ) which represents a moderate strength of agreement between the two techniques.

\section{DISCUSSION}

Of the 158 evaluated samples the detected cytology positivity was $62 \%$ and $75.3 \%$ for culture of all Malassezia species.

The semi-quantitative evaluation of otic cytology is controversial, especially regarding the amount of yeast per field associated with disease, some authors (19) suggest counts greater than 10 cells per field as indicative of disease, while others propose counts less than 5 cells per field $(8,18,20,21)$, however other researchers indicate that the amount of yeast is directly related to the severity of the otitis (2). Given that the samples analyzed in this study were from animals clinically diagnosed with external otitis, these were considered positive if cytology showed $1+$ and were correlated with positive cultures.

Although M. pachydermatis is frequently isolated from external otitis processes, there is not consensous regarding its prevalence as an etiologic agent of the same, being reported between $5.12 \%$ and $76.5 \%(5,19,20)$. In studies done by Boehriger (22) they reported a prevalence of $62 \%$ for cytology and $49 \%$ by culture (morphological macro/ microscopic and Sabouraud agar growth without lipid supplement), the difference between these data could be due to the methodology used in this study, since specific metabolic test were performed which allowed to identify $M$. pachydermatis by $31.1 \%$ and $M$. furfur in $12.6 \%$.

Other Malassezia species reported in external otitis processes in dogs have been $M$. furfur with $3 \%$ and $M$. obtusa by $1.5 \%$ (8) which differs from the findings in this study where the prevalence of the first was $12.6 \%$, while $56.3 \%$ of isolates could not be classified to species level because of atypical reactions in biochemical tests as stated by Crespo et al (9). It is important to note that most studies aimed to the identification of the etiologic agent of otitis processes were performed in dogs using culture media without lipidic supplements, limiting the grow of lipid-dependant species.
(37/119) fue clasificado como M. pachydermatis, $12.6 \%$ (15/119) como M. furfur y el $56.3 \%$ (67/119) correspondió a Malassezia spp. En los frotis correspondientes se observaron diferentes hallazgos citológicos (Tabla 2)

La concordancia observada entre citología ótica positiva para Malassezia Vs. Cultivo positivo fue de 0.76 y el índice Kappa fue 0.448 (95\% CI 0.30 a 0.60 ) lo cual representa una fuerza moderada de acuerdo entre las dos técnicas.

\section{DISCUSIÓN}

De las 158 muestras evaluadas, la positividad detectada mediante citología fue de $62 \%$ y $75.3 \%$ por cultivo para todas las especies de Malassezia.

La evaluación semicuantitativa de la citología ótica es controversial, especialmente en cuanto a la cantidad de levaduras por campo asociadas a enfermedad, algunos autores (19) sugieren recuentos mayores a 10 células por campo como indicativo de enfermedad, mientras otros proponen conteos inferiores a 5 células por campo $(8,18,20,21)$, sin embargo otros investigadores indican que la cantidad de levaduras está directamente relacionada con la severidad de la otitis (2). Dado que las muestras analizadas en este estudio fueron de animales diagnosticados clínicamente con otitis externa, éstos fueron considerados positivos si la citología presentó $1+$ y se correlacionaron con cultivos positivos.

Aunque M. pachydermatis es frecuentemente aislada de procesos de otitis externa, no hay consenso respecto a su prevalencia como agente etiológico de la misma, encontrándose reportes entre $5.12 \%$ y $76.5 \%(5,19,20)$. En estudios realizados por Boehriger (22) se reportó una prevalencia de $62 \%$ para citología y $49 \%$ para cultivo (caracterización morfológica macro/microscópica y crecimiento en agar sabouraud sin suplemento lipídico), la diferencia entre estos datos puede deberse a la metodología utilizada en este estudio, dado que se llevaron acabo pruebas metabólicas específicas para identificar $M$. pachydermatis en un $31.1 \%$ y M. furfur en el $12.6 \%$.

Otras especies de Malassezia reportadas en procesos de otitis externa en caninos han sido del $3 \%$ para $M$. furfur y para M. obtusa de $1.5 \%$ (8) lo que difiere de lo encontrado en este estudio donde la prevalencia para la primera fue de $12.6 \%$, mientras el $56.3 \%$ de los aislamientos no pudieron ser clasificados hasta especie debido a las reacciones atípicas en las pruebas bioquímicas como lo establecen Crespo et al (9). Es importante tener en cuenta que la mayoría de los estudios orientados a la identificación de este agente etiológico en los procesos de otitis en 
Concerning the two techniques, the results of the test showed that Kappa value and concordance test were similar to the ones reported by Boehringer (22), who found a concordance of 0.78 , with a kappa of 0.56 (0.40-0.50), indicating that the tests have moderate agreement.

In conclusion, due to the complexity to identify the etiological agents involved in external otitis and considering that Malassezia is a commensal organism potentially pathogen, the use of a diagnostic test is not enough $(9,22)$ to establish its participation as a cause of disease, especially when there is no response to therapy (8).

\section{Conflict of interest}

The authors declare that they have no conflict of interest.

\section{Acknowledgements}

Authors would like to thank to research vicerectory of the Pontificia Universidad Javeriana for funding. caninos se realizan utilizando medios de cultivo sin los suplementos lipídicos limitando el crecimiento de especies lipodependientes.

Con relación a las dos técnicas, los resultados de la prueba mostraron que el valor Kappa y la prueba de concordancia fueron similares a los reportados por Boehringer (22) quien encontró una concordancia de 0.78 , con Kappa de $0.56(0.40-0.50)$, indicando que las pruebas tienen un acuerdo moderado.

En conclusión, debido a la complejidad para identificar los agentes etiológicos involucrados en otitis externa y considerando que Malassezia es un organismo comensal potencialmente patógeno, el uso de una prueba diagnóstica no es suficiente $(9,22)$ para establecer su participación como agente causal de la enfermedad, especialmente cuando no hay respuesta a la terapia (8).

\section{Conflicto de interés}

Los autores declaran que no tiene conflicto de interés.

\section{Agradecimiento}

Los autores quisieran agradecer a la vicerrectoría de investigación de la Pontificia Universidad Javeriana por su financiamiento.

\section{REFERENCES}

1. Dragonetti AM, Broglia G. Otitis externa canina aproximación al diagnóstico. Vet Cuyana 2007; 1-2:28-33.

2. Zur G, Lifshitz B, Bdolah-Abram T. The association between the signalment, common causes of canine otitis externa and pathogens. J Small Anim Pract 2011; 52:254-258.

3. Girão MD, Prado MR, Brilhante RSN, Cordeiro RA, Monteiro AJ, Sidrim JJC and Rocha MFG. Malassezia pachydermatis isolated from normal and diseased external ear canals in dogs: A comparative analysis. The Vet J 2006; 172:544-548.

4. Khosravi AR, Eid S, Ziglari T, Bayat M. Isolation and Differentiation of Malassezia Species Isolated from Healthy and Affected Small Animals, Ear and Skin. World J Zool 2008; 3(2):77-80.
5. Sarierler M, Kirkan S. Microbiological Diagnosis and Therapy of Canine Otitis Externa. Veteriner Cerrahi Dergisi 2004; 10(3-4):11-15

6. Petrov V, Mihaylov G. Malassezia pachydermatis - etiology and clinical findings in canine external otitis therapeutic approaches. Trakia J Sci (TJS) 2008; 6(1):123-126.

7. Brito EHS, Fontenelle ROS, Brilhante RSN, Cordeiro RA, Monteiro AJ, Sidrim JJC, Rocha MFG. The anatomical distribution and antimicrobial susceptibility of yeast species isolated from healthy dogs. Vet J 2009; 182:320-326.

8. Murphy KM. A review of techniques for the investigation of otitis externa and otitis media. Clin Tech Small Anim Pract 2001; 16(3):236-241. 
9. Crespo MJ, Abarca ML, Cabañes FJ. Occurrence of Malassezia spp. in the external ear Canals of dogs and cats with and without otits externa. Med Mycol 2002; 40:115-121.

10. Rosser EJ. Causes of otitis externa. Vet Clin North Am Small Anim Pract 2004; 34:459-468.

11. Guého E, Midgley G, Guillot J. The genus Malassezia with description of four new species. Antonie van Leeuwenhoek 1996; 69:337-355.

12. Guillot J, Guého $E$, Lesourd M, Midgley G, Chévrier G, Dupont B. Identification of Malassezia species. J Mycol Med 1996; 6:103-110.

13. Sugita $T$, Takashima $M$, Shinoda $T$, Suto $\mathrm{H}$, Unno T, Tsuboi R, Ogawa H, Nishikawa A. New yeast species Malassezia dermatis isolated from patients with atopic dermatitis. J Clinic Microbiol 2002; 41:4695-4699.

14. Hirai A, Kano R, Makimura E, Duarte R, Hamdam M, Lachance A, Yamaguchi A, Hasegawa A. Malassezia nana sp. nov., anovel lipid-dependent yeast species isolated from animals. Int J Syst Evol Microbiol 2004; 54:623-627.

15. Ashbee R, Bignell EM. Pathogenic yeast: The yeast handbook. Berlin: Springer; 2010.

16. Cabañes FJ, Vega S, Castellá G. Malassezia cuniculi sp. nov., a novel yeast species isolated from rabbit skin. Med Mycol 2011; 49:40-48.
17. Angus JC. Otic citology in health and disease. Vet Clin North Am Small Anim Pract 2004; 34:411-424.

18. Fernández G, Barboza G, Villalobos A, Parra O, Finol G, Ramírez RA. Isolation and identification of microorganisms present in 53 dogs suffering otitis externa. Rev Cient FCV-LUZ 2006; 16(1):23-30.

19. Nobre MO, Pötter De Castro A, Nascente PS, Ferreiro L, Meireles MCA. Occurrence of Malassezia pachydermatis and other infectious agents as cause of external otitis in dogs from Rio Grande do Sul state, Brazil (1996/1997). Braz J Mycrobiol 2001; 32:245-249.

20. Crespo MJ, Abarca ML, Cabañes FJ. Atypical lipid-dependent Malassezia species isolated from dogs with otitis externa. J Clin Microbiol 2000; 38(6):2383-2385.

21. Ginel PJ, Lucena R, Rodríguez JC, Ortega J. A semiquantitative cytological evlauation of normal and pathological samples from the ear canal of dogs and cats. Vet Dermatol 2002; 13:151-156.

22. Boehringer SI. Valor diagnóstico del examen citológico en las otitis externas de caninos. Rev Vet 2011; 22:38-42. 